\title{
Harapan pengunjung terhadap perbaikan fasilitas duduk Taman Flora Surabaya
}

\author{
Detyo Campoko*
}

Program Studi Magister Seni Rupa, Program Pascasarjana Universitas Sebelas Maret, Indonesia

\begin{abstract}
Taman Flora Surabaya is one of Surabaya garden that have so many visitors. Having various facilities that can be utilized various circle, this garden has a shortage of design elements of physical seating facilities. This study discusses the opinion of active and rare visitors of Taman Flora Surabaya about how to improvement of sitting facilities. The method used is descriptive qualitative, by respondent opinion technique. The result of the research shows that: 1) active visitors have hope that the facility of Taman Flora Surabaya should be repaired immediately; 2) Jembatan Surabaya is chosen by various stakeholders as icon of sitting facility design to improvement Taman Flora Surabaya.
\end{abstract}

Keywords: visitor, sitting facility, Taman Flora Surabaya

\begin{abstract}
Abstrak
Taman Flora Kota Surabaya merupakan salah satu taman aktif yang banyak pengunjungnya. Memiliki berbagai fasilitas yang dapat dimanfaatkan berbagai kalangan, taman ini memiliki kekurangan dari desain elemen fisik fasilitas tempat duduk. Penelitian ini membahas pendapat pengunjung tetap dan tidak tetap Taman Flora Kota Surabaya tentang perbaikan fasilitas duduk. Metode yang digunakan adalah kualitatif deskriptif, dengan menggunakan teknik dengar pendapat responden. Hasil penelitian menunjukkan bahwa: 1) pengunjung aktif memiliki harapan agar fasilitas duduk Taman Flora Kota Surabaya segera diperbaiki, 2) Jembatan Surabaya paling banyak dipilih berbagai kalangan stakeholder sebagai icon fasilitas duduk Taman Flora Kota.
\end{abstract}

Kata kunci: pengunjung, fasilitas duduk, Taman Flora Kota Surabaya

\section{Pendahuluan}

Surabaya memiliki banyak taman kota, berdasar data DKP saat ini jumlah taman aktif di Surabaya mencapai 54 taman. Sedangkan taman pasif sebanyak 270 taman yang tersebar di empat wilayah Kota Surabaya: barat, timur, selatan dan utara. Hal ini membuat Surabaya untuk kesekian kalinya dinobatkan menjadi yang terbaik untuk kategori kota hijau, dan berhasil meraih penghargaan Indonesia Green Region Award (IGRA) pada 19 Desember 2013. Secara garis besar, taman kota memiliki empat fungsi yang dimiliki RTH yakni fungsi ekologis, sosial, estetis, dan ekonomi. Selain 4 fungsi tersebut Taman kota juga dapat dipakai sebagai indikator indeks kebahagiaan warga kota, serta landmark citra kota yang memberikan nilai estetika pada suatu wilayah. Sukawan menyebutkan bahwa taman kota sebagai Ruang Terbuka Hijau (RTH) merupakan bagian dari ruang terbuka (open spaces) dalam wilayah perkotaan yang diisi oleh tumbuhan, tanaman, dan vegetasi (endemik, introduksi) guna mendukung manfaat langsung atau tidak langsung, beberapa kegunaan yang dihasilkan oleh RTH dalam kota tersebut yaitu: keamanan, kenyamanan, kesejahteraan, dan keindahan wilayah perkotaan tersebut (Hermawan, 2015).

Perbaikan fasilitas menjadi pilihan yang harus dilakukan pemerintah kota Surabaya, sebagai salah satu kiat mempertahankan predikat tersebut. Salah satu yang menjadi prioritas adalah perbaikan fasilitas taman kota yang dimulai dari fasilitas duduk, selain banyak fasilitas lain yang juga perlu dibenahi dan diperbaiki kuantitas serta kualitasnya.

Taman Flora adalah salah satu dari 54 taman aktif di kota Surabaya yang merupakan taman kota

\footnotetext{
* Koresponden penulis e-mail : S011508008@student.uns.ac.id
} 
unggulan, disebut sebagai salah satu taman kota unggulan dikarenakan bukan hanya posisi strategis yang terletak di jantung kota Surabaya namun taman ini juga merupakan pusat pembibitan tanaman hijau yang didalamnya sarat fasilitas yang terbilang lengkap untuk sebuah taman kota yang dapat dinikmati warga secara gratis.

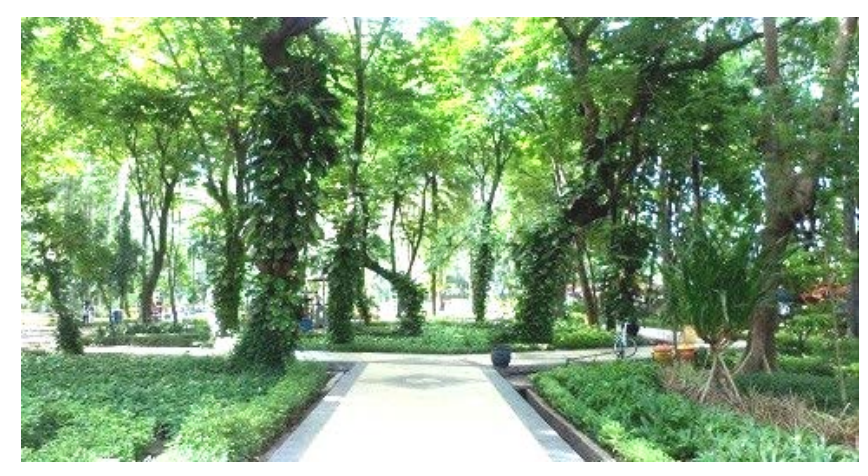

Gambar 1. Pusat pembibitan tanaman

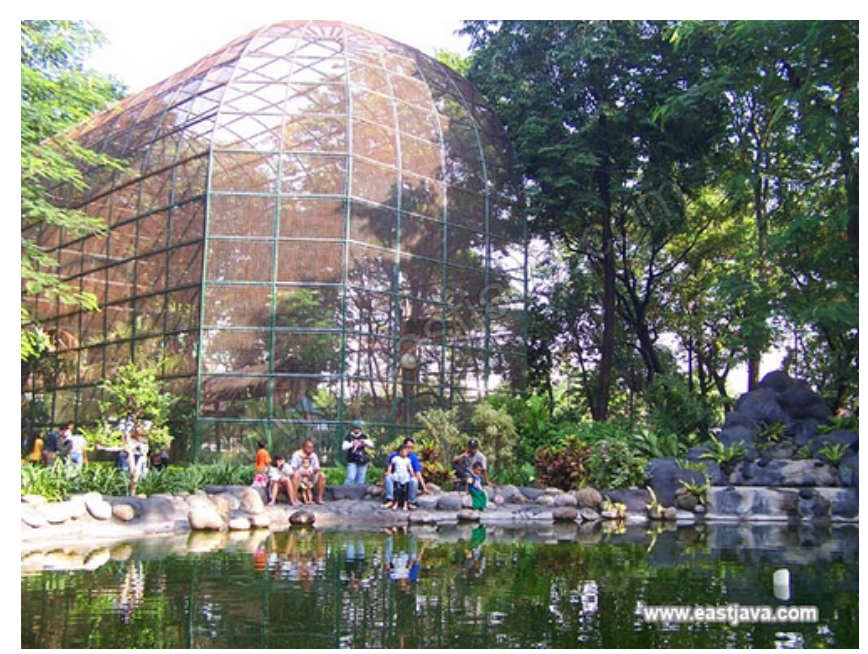

Gambar 2. Sangkar burung raksasa Sumber: www.eastjava.com

Terdapat ratusan tanaman hias dan bunga dengan beberapa kolam ikan lengkap dengan pancuran air, keistimewaan Taman Flora ini didukung dengan keberadaan kebun binatang mini yang di dalamnya terdapat koleksi hewan rusa, kelinci dan berbagai jenis spesies burung juga dipelihara dalam sangkar yang cukup besar sehingga menambah daya tarik masyarakat untuk datang. Taman Flora juga dikonsep sebagai technopark yang dilengkapi dengan akses internet gratis berkecepatan tinggi. Fasilitas ini diharapkan dapat dimanfaatkan pengunjung untuk membentuk komunitas belajar. Mengingat pentingnya keberadaan taman tersebut, perlu dilakukan riset untuk meningkatkan kualitas sarana yang dimilikinya. Riset ini bertujuan untuk memperoleh gambaran tentang harapan dari para pengunjung Taman Flora Surabaya selaku user khususnya yang terkait dengan sarana duduk. Riset ini diharapkan akan memunculkan kriteria-kriteria desain sebagai dasar perancangan sarana duduk di kawasan taman tersebut.

\section{Bahan dan Metode}

Awal pembukaan Taman Flora tahun 2007 berbagai fasilitas penunjang utama berupa street furniture yang terdiri dari sarana duduk belum dirancang sesuai dengan konsep yang diharapkan dapat mengakomodasi kebutuhan pengunjung yang terdiri dari semua lapisan masyarakat yang beraktivitas dan yang sekedar menikmati kesejukan taman. Sarana duduk yang ada hanya dibuat dengan bentuk yang seadanya, hal ini dapat dimaklumi karena sejak awal berdirinya taman kota, alokasi anggaran hanya dikonsentrasikan pada pembibitan jenis tanaman, sedangkan desain fasilitas duduk taman hanya bersifat pelengkap (Gambar 3).

Sejak taman kota mulai ramai dikunjungi masyarakat sebagai salah satu alternatif tujuan wisata kota dan seiring dengan kebijakan pemerintah kota untuk mempertahankan predikat sebagai kota hijau dengan taman yang indah maka pemerintah kota Surabaya menyadari akan perlunya melakukan rekondisi dan redesain berbagai elemen fisik taman kota berupa sarana duduk agar tampil dan berfungsi lebih baik dari yang sudah ada.

Participatory design adalah pendekatan yang dilakukan perancang dengan menjadikan pengguna (user) sebagai obyek dan subyek sekaligus dalam mengetahui tingkat kebutuhan akan fungsi dari fasilitas duduk yang sesuai dengan target pengguna (user) (B.-N.Sanders, 2002). Jayadi dan Prasetya menyebutnya sebagai friendly design, yaitu desain yang dihasilkan dari dialog dengan masyarakat sebagai user (Jayadi \& Prasetya, 2017, 2018). Pendekatan partisipatory dalam perancangan fasilitas duduk taman kota Surabaya ini penting untuk membangun ketertarikan dalam menggunakan fasilitas tersebut sehingga nantinya diharapkan akan tumbuh rasa memiliki bersama yang akan mengurangi dampak vandalisme yang banyak terjadi pada fasilitas pada umumnya. Model pendekatan partisipatif dalam mengembangkan perancangan bidang desain produk juga mengarahkan pendekatan yang lebih operasional untuk mencari penyelesaian permasalahan yang ada pada fasilitas duduk. 


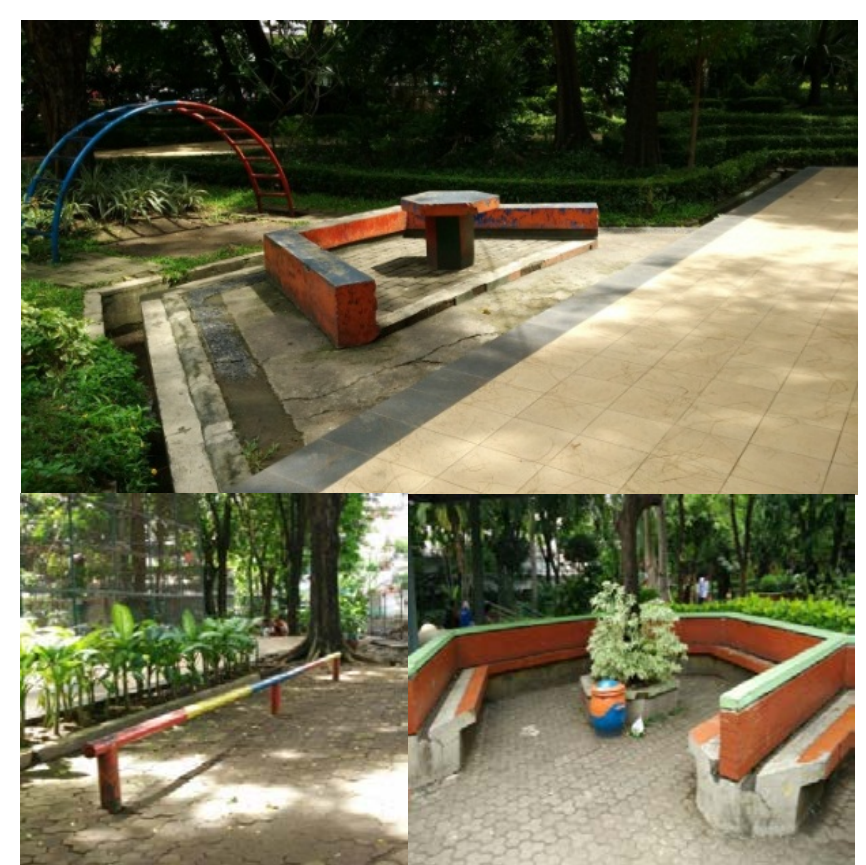

Gambar 3. Kondisi sarana duduk Taman Flora

Metode participatory dibagi menjadi 2 tahapan yaitu partisipasi pasif dan partisipasi aktif. Pada perancangan produk kali ini perancang merencanakan konsep fasilitas sarana duduk dengan pendekatan design partisipatory yang menggali berbagai aktivitas yang berujung pada berbagai kebutuhan pengguna fasilitas duduk taman yang berasal dari pengunjung aktif maupun pasif baik yang berdomisili di sekitar taman flora kota Surabaya maupun pengunjung dari luar kota.

Penerapan kebijakan pemerintah yang bersifat top down seringkali menghasilkan sesuatu yang tidak sesuai dengan harapan masyarakat dan diharapkan dengan partisipasi aktif akan menghasilkan sesuatu yang sesuai dengan keinginan dan kebutuhan masyarakat. Dengan melibatkan berbagai pihak dari stakeholder maupun penggunna yang sering memanfaatkan Taman Flora, maka diharapkan hasil perancangan akan sesuai dengan sasaran,selain itu salah satu strategi untuk menjaga keberlanjutan (sustainabiity) adalah dengan melibatkan partisipasi masyarakat aktif menjaga dan merawat fasilitas yang telah dibangun, dari partisipatif aktif maka akan timbul rasa memiliki dan menjaga fasilitas bersama sehingga berbagai masalah terkait dengan fandalisme pada fasilitas umum dapat diminimalisir elemen taman disini hanya mencakup infrastruktur fisik berupa elemen perkerasan meliputi bangku taman dan kursi taman.

Taman Flora dipilih sebagai obyek studi karena taman ini mempunyai banyak kelebihan yang mampu mewakili keberadaan puluhan taman yang ada di seluruh wilayah kota Surabaya. Salah satunya adalah kelengkapan fasilitasnya, sehingga diharapkan hasil perancangan nanti cukup ideal untuk digunakan sebagai standar acuan desain sarana duduk taman kota untuk seluruh wilayah Kota Surabaya.

Metode yang dipakai dalam riset ini adalah metode kualitatif deskriptif dengan teknik etnografi. Penelitian kualitatif deskriptif bertujuan untuk meningkatkan pemahaman tentang suatu masalah melalui pendeskripsian secara rinci dan mendalam mengenai kondisi real objek penelitian. Definisi responden mengacu pada pendapat Lexy J. Moleong yang menyatakan bahwa responden merupakan orang yang dimanfaatkan untuk memberikan informasi tentang situasi dan kondisi latar penelitian (Moleong, 2014). Dalam penelitian ini penentuan responden dipilih secara acak yang berkunjung pada hari kerja dan hari libur. Responden merupakan pengunjung aktif yang berada di Taman Flora Surabaya, Jl. Raya Manyar No 80A Kelurahan Barata Jaya Kecamatan Gubeng, Kota Surabaya.

\section{Hasil dan Pembahasan}

Wawancara dilakukan terhadap 4 kelompok responden, yaitu (1) kelompok paruh baya dan lansia, (2) kelompok keluarga, (3) kelompok remaja, pelajar, dan mahasiswa, dan (4) kelompok anak-anak TK dan Paud. Data kelompok paruh baya dan lansia diperoleh melalui wawancara dengan Bapak Purwanto. Lakilaki paruh baya tersebut merupakan ketua kelompok kegiatan warga RW 1 dan 2 Kelurahan Barata Jaya yang beranggotakan 30 lansia. Kelompok warga ini memakai Taman Flora Kota Surabaya untuk berbagai macam kegiatan warga yang memungkinkan dilakukan di luar ruang, seperti: senam lansia, ibu-ibu PKK, olah raga dan arisan warga. Berbagai kegiatan ini dilakukan di Taman Flora karena lingkungan di sana, menurut mereka sangat nyaman dan asri sehingga warga lebih memilih berkegiatan di luar ruang yang berlokasi di Taman Flora. Sekalipun demikian, kegiatan yang dilakukan warga tidak serta merta bisa dilakukan. Hal ini disebabkan adanya prosedur perijinan kegiatan yang harus diurus melalui pengelola Taman Flora, mulai dari jenis kegiatan jumlah peserta dan waktu yang dibutuhkan serta sarana yang digunakan. Dari hasil wawancara kelompok pengunjung jenis ini didapat masukan terkait dengan desain bangku sarana duduk taman yang ideal untuk kebutuhan pengunjung kelompok usia paruh baya dan lansia yaitu: pertama, secara kuantitas, sarana duduk yang dapat digunakan berkelompok masih terbatas. Posisi peletakannya pun 
berada pada lokasi-lokasi yang kurang sesuai digunakan untuk kegiatan berkelompok. Bagi mereka, keberadaan sarana duduk menjadi sangat penting terutama untuk kegiatan istirahat setelah senam maupun olah raga. Usia 50 tahun ke atas akan kesulitan jika duduk tanpa bantuan sarana duduk. Kedua, mereka menganggap penting keberadaan sarana duduk yang mampu dipakai untuk kegiatan bersama secara berkelompok seperti: arisan warga, sarasehan atau acara penyuluhan kesehatan untuk usia lanjut. Dan yang ketiga, kalangan usia 50 tahun ke atas sebagian besar menghabiskan waktu berkunjungnya di taman tersebut dengan aktivitas duduk dan mengobrol satu dengan lainya.

Wawancara terhadap kelompok pengunjung keluarga kecil, yang terdiri dari dua sampai tiga anak yang datang berkunjung satu kali dalam sepekan melibatkan 9 orang responden, yaitu Bapak Sigit, Bapak Yohanes, Ibu Agatha, Bapak Roni, Bapak Ridwan, Bapak Bayu, Bapak Yudi, Bapak Joni, dan keluarga Ibu Dian. Kesembilan keluarga kecil ini mempunyai latar belakang yang hampir sama, yaitu keluarga muda yang mempunyai anak 1-2 orang, dengan tingkat ekonomi menengah dan berdomisili tak jauh dari Taman Flora. Mereka memanfaatkan Taman Flora setiap akhir pekan untuk sekedar menikmati udara segar dan berkumpul bersama serta sesekali menemani anak-anaknya untuk bermain di taman. Hasil rangkuman wawancara dengan mereka didapat beberapa kebutuhan akan sarana duduk yaitu: desain bangku/tempat duduk cukup lega digunakan untuk duduk bersama.

Beberapa data lainnya yang diperoleh dari responden kelompok ini antara lain adalah (1) Desain bangku/ kursi taman mempunyai dudukan yang nyaman dan tidak keras dan tidak mudah capek jika diduduki dalam jangka waktu relatif lama. (2) Pengunjung tipe keluarga ini cenderung aktif menggunakan tempat duduk. Dari 3 jam kunjungan ke taman, 2 jam diantaranya dihabiskannya dengan duduk-duduk. (3) Desain bangku/ kursi yang ada sangat terbatas jumlahnya terutama pada area taman binatang/ kandang rusa dan sangkar burung. Di sana sangat sulit mencari tempat duduk dan kalaupun ada, tempat duduknya tidak nyaman dan tidak terdapat sandaran punggung. (4) Aktivitas duduk untuk kelompok pengunjung tipe keluarga ini pada saat duduk selalu dibarengi dengan mengkonsumsi makanan ringan dan minuman dengan kemasan plastik,sehingga kebutuhan akan membuang sampah untuk jenis pengunjung tipe ini sangat tinggi. (5) Pada saat panas dan hujan gerimis keberadaan tempat berteduh sangat minim. Kalaupun ada, hanya di bawah pohon yang tidak dapat melindungi penuh dari air hujan dan terik panas matahari. Apalagi jika keberadaan sarana duduk berada di tanah yg tidak terlindungi oleh pepohonan yang rindang.

Responden berikutnya adalah kelompok pengunjung remaja/pelajar/mahasiswa. Terdapat 82 responden yang terdiri dari 10 orang pelajar SMP, 25 orang pelajar SMU dan 47 orang mahasiswa. Pada umumnya, mereka datang secara berkelompok antara 5-10 orang atau dalam kelompok kecil 2-4 orang. Jika hari dan jam kerja, pelajar yang datang akan dimintai surat pengantar dan harus didampingi oleh pembimbing. Tidak demikian halnya dengan mahasiswa yang bebas datang ke taman pada jam dan hari kerja, namun akan dimintai surat ijin penelitian jika melaksanakan aktivitas dokumentasi dan pengambilan data. Posisi keberadaan mereka jika berada di Taman Flora biasanya akan mendekati titik spot internet gratis terdekat, mengingat keberadaan wifi hotspot gratis.

Taman Flora terletak tepat di tengah kawasan perkantoran, pusat pertokoan, dan perdagangan Manyar Surabaya. Beberapa kampus pendidikan tinggi juga berlokasi tak jauh dari kawasan Taman Flora Surabaya tersebut, seperti PERBANAS, UNTAG, UNITOMO, UBAYA, STTS, STIBA, STKW, sehingga komunitas pengunjung Taman Flora banyak dari kalangan mahasiswa kampus-kampus tersebut. Beberapa pendapat yang merupakan masukan dari kelompok pengunjung ini adalah: (1) Desain yang ada, tidak mengakomodasi kebutuhan untuk menulis dan mengoperasikan komputer jinjing/ laptop. Artinya, menurut mereka desain sarana duduk yang baik di samping nyaman dipakai juga mampu mengakomodasi kebutuhan menulis, menggambar, ataupun mengoperasikan laptop. (2) Tidak tersedia stop kontak pada sarana duduk sehingga pada saat mengoperasikan gadget selalu mengalami kendala dan kesulitan dalam mencari sumber listrik. Pengelola hanya menyediakan saluran listrik pada bangunan pusat komputer yang pada jam-jam tertentu harus antri hanya untuk mengisi batere laptop. (3) Sarana duduk yang sudah ada di Taman Flora terasa kasar teksturnya dan keras karena terbuat dari bahan semen. Kalaupun ada yang terbuat dari pipa besi pasti kondisinya sudah berkarat. Jika harus duduk dan bekerja dengan laptop mereka memilih duduk di bawah meskipun tidak nyaman dan dengan konsekuensi perangkat elektroniknya lebih beresiko rusak. (4) Menurut Roby yang mempunyai latar belakang mahasiswa bidang seni dan Aldo yang juga merupakan mahasiswa berlatar belakang jurusan desain, bentuk dari sarana taman duduk di Taman Flora ini sama sekali tidak memiliki daya tarik secara visual dibandingkan dengan beberapa sarana duduk di 
taman kota lain yang pernah mereka singgahi. Pendapat sejenis juga dilontarkan oleh sekelompok mahasiswa ekonomi dari kampus yang berlokasi di sekitar Taman Flora.

Taman Flora satu-satunya taman kota di Surabaya dengan fasilitas taman paling lengkap, fasilitas yang membuat daya tarik taman kota ini menjadi taman paling ramai dengan tingkat kunjungan tertingi dibanding taman-taman lain, hal ini tak lepas dari peran pengelola dalam melengkapi sarana dan prasarana bermain dan rekreasi untuk anak dan keluarga, kebun binatang mini yang berisi koleksi rusa dan kancil dan beberapa burung di sangkar besar merupkan daya tarik yang tinggi selain keberadaan aneka wahana bermain untuk anak anak, beberapa sekolah pendidikan taman kanak kanak dan pendidikan usia dini yang berada bukan hanya di Kecamatan Gubeng Kertajaya namun juga kecamatan lain di Surabaya berbondong-bondong mengunjungi taman ini pada hari kerja maupun hari libur.

Data dari responden kelompok anak-anak TK dan PAUD ini diperoleh dengan melakukan wawancara terhadap salah satu guru taman kanak-kanak Yayasan Cendekia Kecamatan Rungkut, yang membawa murid-muridnya berkunjung di Taman Flora. Berkaitan dengan dengan pemanfaatan sarana duduk dan fasilitas bangku taman oleh anak-anak taman kanak-kanak dan PAUD, maka diperoleh ringkasan informasi sebagai berikut: (1) Mereka sering mengadakan acara berlatih menggambar di alam terbuka dengan obyek tanaman, bunga dan hewan. Pada lokasi-lokasi pelaksanaan kegiatan tersebut, seringkali tidak dijumpai sarana duduk yg representatif. Titik-titik lokasi tersebut biasanya berada di sekitar kandang rusa atau tempat-tempat lainnya. Kalaupun ada, ukuran sarana duduk yang tersedia terlalu besar bagi postur tubuh anak-anak. (2) Anak-anak sering memakai sarana duduk yang sudah ada yang terbuat dari concrete/cor semen dan batu bata untuk mereka bermain dan belajar. Secara ukuran tempat duduk tersebut dikhususkan untuk pengguna dewasa, sehingga mereka berharap ada desain yang juga mengakomodasi kebutuhan anak-anak sebagai pengunjung yang sangat aktif memanfaatkan Taman Flora sebagai kawasan belajar luar ruang. Dan (3) mereka juga mengharapkan desain sarana duduk yang mengakomodasi kebutuhan anak-anak, misalnya yang dapat digabungkan dengan sarana bermain. Sehingga nantinya Taman Flora juga mempunyai daya tarik sebagai taman bermain dan pusat belajar yang atraktif untuk masyarakat Kota Surabaya.

Berdasarkan hasil wawancara dengan responden, terdapat beberapa temuan, yaitu: secara umum, terdapat kriteria-kriteria yang harus diperhatikan (issues of concern) dalam merancang sarana duduk taman, yaitu kenyamanan, keamanan \& keselamatan, daya tarik dan keindahan, utilitas atau fungsi, dan jenis perilaku dan kegiatan pengguna. Untuk memenuhi target tersebut maka beberapa fokus akan menjadi perhatian khusus terkait dengan kriteria tersebut (scope of issues) yaitu perilaku pengguna, kebutuhan pengguna, jenis konstruksi, material serta aspek perawatan.

Tabel 1. Kriteria desain dan indikatornya

\begin{tabular}{lll}
\hline NO & KOMPONEN & \multicolumn{1}{c}{ INDIKATOR } \\
\hline 1 & Fungsi/ utility & $\begin{array}{l}\text { Memenuhi kebutuhan atas sarana } \\
\text { duduk yang dipakai oleh semua } \\
\text { pengunjung yang terdiri dari berbagai } \\
\end{array}$ \\
& & lapisan dan golongan.
\end{tabular}

\begin{tabular}{|c|c|c|}
\hline 2 & $\begin{array}{l}\text { Kenyamanan/ } \\
\text { amenity comfort }\end{array}$ & $\begin{array}{l}\text { Memenuhi nilai kenyamanan } \\
\text { terhadap sarana duduk yang akan } \\
\text { dipakai pengunjung dengan } \\
\text { memperhatikan aspek ergodesign } \\
\text { sebuah kursi taman yang mempunyai } \\
\text { tingkat kebutuhan pemakai yang } \\
\text { berbeda. }\end{array}$ \\
\hline
\end{tabular}

\begin{tabular}{lll}
\hline Keamanan dan & Memperhatikan aspek keamanan \\
Keselamatan & produk dengan melihat klasifikasi \\
/safety & peruntukan kursi sesuai dengan jenis \\
& kegiatan dan kebutuhan masing \\
& masing pengguna,dari pengguna \\
& golongan anak, remaja dewasa \\
& keluarga dan kelompok lanjut usia. \\
& memperhatikan aspek teknis fisik \\
& dari mulai bentuk, konstruksi, \\
& material, finishing pada setiap \\
& rancangan produk . \\
& \\
\end{tabular}

$4 \quad$ Estetika dan daya $\quad$ Daya tarik dan estetika merupakan tarik/ visual pertimbangan penting berhasil interest tidaknya perancangan mampu memberikan kesan visual yang diharapkan mampu menjadi kekuatan tak terlihat dari penggunanya untuk berusaha ikut menjaga dan merawatnya.

\begin{tabular}{ll}
\hline $5 \quad$ Kegiatan (activity) & Perilaku pengguna yang merupakan \\
& aktivitas pengunjung yang \\
& memanfaatkan sarana duduk sangat \\
& berpengaruh banyak dalam banyak \\
& aspek perancangan.
\end{tabular}

Berdasarkan data-data di atas diperoleh kesimpulan bahwa secara umum fasilitas duduk yang berada di 
Taman Flora ini belum mempunyai kualitas yang baik. Oleh karena itu dibutuhkan desain sarana duduk taman kota yang komprehensif; yang mempertimbangkan berbagai aspek serta kriteria sebagai sarana duduk taman kota yang ideal untuk Taman Flora Surabaya.

Uraian di atas mengerucut pada 5 hal yang merupakan bagian 10 prinsip perancangan fasilitas umum menurut Urban Design Plan of San Fransisco 1970 yaitu, (1) utilitas atau fungsi, (2) kenyamanan, (3) keamanan dan keselamatan, (4) daya tarik dan keindahan, serta (5) aktivitas perilaku (Aidala, 1970). Kelima hal tersebut pada langkah selanjutnya menjadi 5 kriteria desain. Di dalam 5 kriteria tersebut terdapat urutan kepentingan dalam pemenuhannya. Kriteria fungsi dan kenyamanan berada pada prioritas utama, kriteria keamanan dan daya tarik serta estetika berada pada prioritas kedua, serta kriteria kegiatan berada pada prioritas ketiga. Lima komponen tersebut perlu diatur untuk mencapai kualitas sarana duduk taman yang sesuai dengan nilai ideal yang diharapkan. Oleh karenanya, setiap komponen memiliki indikator tertentu sebagai tolok ukur pencapaian kriteria yang diwakilinya. Indikator untuk masing-masing komponen berdasarkan urutan kepentingannya dapat dilihat pada Tabel 1.

\section{Kesimpulan}

Riset ini menyimpulkan bahwa harapan masyarakat pengguna terhadap desain sarana duduk di Taman Flora Surabaya berhubungan dengan 5 hal, yaitu fungsi, kenyamanan, keamanan/keselamatan, estetika, dan aktivitas. Oleh karenanya, kelima hal tersebut dapat dijadikan sebagai kriteria perancangan sarana duduk di lokasi tersebut. Keberhasilan kriteria-kriteria tersebut dapat diukur melalui indikator-indikator pada Tabel 1.

Riset selanjutnya diharapkan fokus pada tindaklanjut perancangan berdasarkan kriteria tersebut yang menghasilkan output berupa desain sarana duduk yang memenuhi harapan masyarakat pengunjung Taman Flora Surabaya sebagai pengguna.

\section{Daftar pustaka}

Aidala, T. R. (1970). Preliminary Report No. 5 Urban Design Principles for San Francisco. San Francisco.

B.-N.Sanders, E. (2002). From user-centered to participatory design approaches. In J. Frascara (Ed.), Design and the Social Sciences. New York: Taylor \& Francis Inc.

Hermawan, A. (2015). Tingkat keberhasilan program peningkatan fasilitas Ruang Terbuka Hijau (RTH) terhadap pemanfaatan taman kota di Kecamatan Kota Kabupaten Kudus. Jurnal Pembangunan WIlayah Dan Kota, 11(3), 261-271.

Jayadi, N., \& Prasetya, R. D. (2017). Persepsi masyarakat terhadap desain kamuflase menara BTS di lingkungan perkotaan Studi kasus: Kota Yogyakarta. In International Symposium of Art, Craft, and Design in Southeast Asia (pp. 77-98). Yogyakarta. Retrieved from https://www.researchgate.net/publication/321148943_Persepsi _Masyarakat_terhadap_Desain_Kamuflase_Menara_BTS_di_ Lingkungan_Perkotaan_Studi_Kasus_Kota_Yogyakarta

Jayadi, N., \& Prasetya, R. D. (2018). Penguatan eksistensi kota kreatif melalui inovasi desain kamuflase menara BTS berbasis zonasi wilayah. PRODUCTUM Jurnal Desain Produk (Pengetahuan Dan Perancangan Produk), 3(3), 101-106.

Moleong, J. (2014). Metodologi Penelitian Kualitatif. Bandung: Remaja Rosdakarya. 